\title{
Short-term effects of carrying a school bag on the distribution of force and plantar pressure during walking of children of different levels of physical activity
}

\author{
Dijana Laštro', Mirsad Muftić2, Nenad Ponorac³ , Goran Talic', Slavica Janković4 \\ 'Institute for Physical Medicine and Rehabilitation "Dr. Miroslav Zotović," Banja Luka, Republic of Srpska, Bosnia and Herzegovina, \\ 2Department of Physical Therapy, Faculty of Health Studies, University of Sarajevo, Sarajevo, Federation of Bosnia and Herzegovina, Bosnia \\ and Herzegovina, ${ }^{3}$ Department of Physiology, Faculty of Medicine, University of Banja Luka, Banja Luka, Republic of Srpska, Bosnia and \\ Herzegovina, ${ }^{4}$ Department of Physical Therapy, University of Applied Sciences "Lavoslav Ruzicka," Vukovar, Croatia
}

\begin{abstract}
Introduction: Carrying a school bag is a dominant activity that a child performs during daily productive activities. The aim of the research is to examine how carrying a school bag of different weights affects the distribution of force and plantar pressure during normal walking on the flat terrain of children of varying levels of physical activity.

Methods: The pilot study included 124 students aged 11-12 from Banja Luka. According to the protocol, each group of respondents was treated with an intervention-customized school bag and a comparator-school bag that the child only opted for. For the research, the Physical Activity Questionnaire for Older Children, measurement of anthropometric parameters, school bag weight, and Zebris tape (Zebris Medical GmbH, Germany) were used for gait analysis.

Results: Inactive children achieved the lowest and active children's highest walking speed during normal walking without a bag, with their customized school bag. When carrying a custom school bag: The highest maximum force is projected on the left heel $330.72 \mathrm{~N}$ in inactive children, and the lowest $265.93 \mathrm{~N}$ in moderately active children, the highest maximum pressure on the left heel is registered in inactive children, $27.60 \mathrm{~N} / \mathrm{cm}^{2}$, and the lowest $21.85 \mathrm{~N} / \mathrm{cm}^{2}$ in moderately active children. The maximum force-time of $\%$ of standing time on the left foot in the middle part lasted the longest in inactive children, and the shortest active children carried their school bag $40.31 \%$ and a custom school bag 39.76\%.

Conclusion: High physical activity and individual adjustment to distribute the burden well allow the child to adequately respond to the loads carried by the weight of the school bag.
\end{abstract}

Keywords: Primary school children; school bag; physical activity; gait analysis

\section{INTRODUCTION}

Carrying a school bag is a dominant activity that begins at the age of 4-18, and the child performs it in performing daily productive activities. The contents of the school bag change significantly during the educational process. The most significant change occurs with the transition from a class to subject teaching in the pre-period of accelerated growth and development. In recent years, nonspecific back pain, neck pain, shoulder pain, and poor posture among school children have increased importance in the literature. These conditions have been associated mainly with congestion caused by heavy school bags (1-3). Diseases due to lack of movement and physical inactivity

Correspondence author: Dijana Laštro, Institute for Physical Medicine and Rehabilitation, Dr. Miroslav Zotovic Banja Luka, Slatinska 11, 78000 Banja Luka, Bosnia and Herzegovina. E-mail: dijana.lastro@med.unibl.org

Submitted: 30. April 2021/Accepted: 30. June 2021

DOI: https://doi.org/10.17532/jhsci.2021.1329 can be considered a significant pathogenic condition factor (4). Inactive lifestyle leads to the uneven development of muscle groups and some other environmental factors (improper sitting) that can lead to improper posture. The U.S. Department of Health, in its second edition of the Physical Activity Guidelines for Americans (PAG), recommended that children and adolescents ages 6-17 should work 60 minutes or more daily in moderate to vigorous physical activity (5). For some authors, the distance and time a child spends walking with a school bag to and from school also poses a risk to the child's spine $(6,7)$. One group of authors states that using a school bag can contribute to postural changes, such as correcting lumbar lordosis and thoracic kyphosis, and thus cause immediate changes in spinal curvature $(8,9)$, impaired static balance $(10)$, stairs and movement (walking, brisk walking, running, jumping, etc.), and (11). The American Association for Occupational Therapy, the American Academy of Orthopedic Surgeons, and the International Association of Pediatric Chiropractors 
suggest that the load should not exceed $10 \%$, the American Association for Physical Therapy 15\%, and the American Association of Chiropractors 5-10\% (12). Changes are noticeable when carrying a school bag weighing $20 \%$ of body weight. These changes are reflected in a decrease in speed and stride length, and an increase in the duration of the double phase of support, increased stride frequency, and reduced swing time $(9,13)$. In children and adolescents, there is a strong inverse correlation between plantar pressure and physical activity levels $(14,15)$. Assessment of plantar pressure may signal different postural changes in feet related to foot-level forces while standing and walking in both healthy subjects and various pathologies like obesity. Plantar pressure provides information on changes due to pain reported at the lower extremity level and stability disorders (16). The World Health Organization has defined obesity as a global epidemic. There is still a lack of preventive programs that would prevent, or at least alleviate, the progressive growth of physical inactivity and overweight, the occurrence of musculoskeletal pain among children and adolescents. Although the American Association of Occupational Therapists (AOTA, 2014) has issued guidelines for the proper use of a school bag, we lack such prevention programs (17).

The aim of the study was to examine how carrying a school bag of different weights affects the distribution of force and plantar pressure during normal walking on the flat terrain of children of different levels of physical activity. The main hypothesis for this research was that active children during an everyday walk with an adapted school bag have a significantly reduced force distribution, but not a generalization of peak pressure values.

\section{METHODS}

The research was a pilot study according to the Patient/ Population, Intervention, Comparison, Outcome (PICO) methodology PICO. Using the cluster sampling method, the study included 737 students of both sexes aged 11-12, seven city primary schools from Banja Luka. After meeting the criteria for inclusion and testing of students with the Physical Activity Questionnaire The Physical Activity Questionnaire for Older Children (PAQ-C) (18,19), respondents entered the study successively. They were divided into three groups: Active, moderately active, and inactive children. The study included 124 students of both sexes and 613 students of both sexes not included.

Study included children older than primary school age 11-12, both sexes, children who have signed written consent of a parent or legal representative, children who have given permission and signed written consent to participate, and children who have the ability to self-ambulance.

From study are excluded children with intellectual disabilities, epilepsy, cerebral palsy, hemiparesis, diabetes mellitus, heart and circulatory diseases, respiratory system, children with a history of fractures or injuries of the lower extremities in the past year, children without signed parental consent or legal representatives, and children who have not given their consent to participate and children who use a mobility aid, fatigue, pain, inability to adapt to the work of the zebra strip were excluded from the study.
The research was approved by the Ministry of Education and Culture of Republika Srpska, heads of primary schools in local self-government in Banja Luka, head of the Institute for Physical Medicine and Rehabilitation "Dr Miroslav Zotovic" Banja Luka, and the Ethics Committee of the Medical Faculty of the University of Banja Luka. All respondents and parents gave their voluntary consent, which, in addition to the oral explanation, was also contained in the informed consent and written information for parents and students. The research was conducted during the 2019/2020 school year. Subjective and objective tests were used for the research.

As a subjective test, we used a PAQ-C physical activity questionnaire consisting of 9 questions specially evaluated on a 5-point scale. The total result of physical activity is predicted at the arithmetic mean of the given answers, especially assessed on a scale from 1 to 5 . According to the given criteria, the questionnaire enables the classification of respondents (result 1-2 - inactive, 3 - moderately active, and 4-5 - active children) $(18,19)$.

As an objective test, we used body mass index (BMI) as the ratio of body mass (BM) to the square of body height $(\mathrm{BH}) . \mathrm{BM}$ is expressed in kilograms and $\mathrm{BH}$ in meters (WHO, 2018). Nutritional status was assessed by applying a standard BMI according to the criteria (WHO, 2000) and by classifying values according to percentile curves for boys and girls aged 5-19 years (WHO, 2007) according to standard limit values. The obtained result classifies the child into five categories: obese, increased body weight, normal body weight, malnourished and undernourished (20).

The weight of the school bag is determined by the differences between the two weights and will represent the weight of the school bag. The percentage ratio of body weight to school bag weight is obtained by multiplying the school bag weight by 100 and dividing by the body weight $(21,22)$.

Walking performance was assessed on a multifunctional Zebris tape (Zebris Medical GmbH, Germany) for gait training and analysis. The Zebris system consists of a conveyor belt with a diameter of $158 \mathrm{~cm} \times 60.1 \mathrm{~cm}$, containing a sensor surface with a diameter of $149 \mathrm{~cm} \times 54.2 \mathrm{~cm}$ with 11,264 sensors, technical, and computer elements. Recording on the Zebris belt requires the preparation of respondents. Adjustment begins at a speed of 0.5 kilometers per hour $(\mathrm{km} / \mathrm{h})$ and then increases by $0.3 \mathrm{~km} / \mathrm{h}$ every 15 seconds (sec) by one step until the subject informs that the speed that best characterizes their normal, normal gait has been reached. After a 10-min adaptation phase, the system is ready to record for $30 \mathrm{sec}$. Due to the high density of the sensor, the foot is mapped at a high resolution, allowing the registration of subtle changes in the distribution of force and pressure (23).

Predictor variables in our study represent the value of the total score of physical activity (inactive, moderately active, and active children), and dependent variables represent contact time, maximum force, maximum force time, maximum pressure and which are determined separately for the back, middle, and front of the foot on both sides. Load transfer time for which the load is transferred from the back to the front of the foot on both sides.

Testing of children with the PAQ-C Physical Activity 
Questionnaire was performed at school and objective measurements in the Cabinet for gait analysis in the Institute for Physical Medicine and Rehabilitation "Dr Miroslav Zotović” Banja Luka Department II (Figure 1).

Each respondent was required to bring their school bag for testing. According to their assessment, they were supposed to get the contents of the school bag (textbooks, notebooks, school supplies, physical education equipment, and additional contents he brings to school every day) from 1 working day, which he considered the heaviest school bag of the week.

Their school bag was customized according to the guidelines of the American Association of Occupational Therapists and whose weight is $10 \%$ of their body weight (17). Before arrival, subjects were advised to eat $2 \mathrm{~h}$ before testing, ingest sufficient fluids, and perform physiological needs. Each respondent has individually explained the procedure on the Zebris bar according to the recommendations for using the Zebris Software Manual zebris FDM (24). After a 10-min adaptation period on the Zebris strip, each measurement with a different school bag weight lasted $30 \mathrm{sec}$. Measurement of anthropometric parameters, school bag weight took $30 \mathrm{~min}$, and Zebris tape testing $15 \mathrm{~min}$.

The research was conducted by a research team consisting of the principal researcher, occupational therapist-physiotherapist, occupational therapist, physical education teacher, and doctor. One examiner measured the Zebris strip and measured anthropometric parameters and characteristics of the school bag by two surveyors. Before the start, training was conducted by the principal investigator, and a work diary was kept following the study protocol.

Complete statistical analysis of data was done with the statistical software package, SPSS Statistics 18. Most of the variables were presented in a text and table as frequency (\%) of specific categories. In continuous data, variables were presented as mean value \pm standard deviation, minimum and maximal values. Kolmogorov-Smirnov test was used to evaluate the distribution of continual data. Statistical significance between groups was tested by ANOVA tests for independent or repeated measures. In case of finding a significant difference between groups, the post hoc Tukey test was applied.

All the analyzes were estimated at a $p<0.05$ level of statistical significance.

\section{RESULTS}

The description of the sample, values of anthropometric parameters, BMI, and school bag weight are presented in Tables 1-3 concerning gender and total population, and graphically (Graph 1) the level of physical activity. Table 4 shows the results of the analysis of variance on the short-term effects of carrying a school bag on the distribution of force and plantar pressure during normal walking on flat terrain only where a statistically significant difference between three predictors and 29 dependent variables was found. The values of the t-test results are expressed in Newton's $(\mathrm{N})$, newtons per square centimetre $\left(\mathrm{N} / \mathrm{cm}^{2}\right)$, percentages $(\%)$, kilogram $(\mathrm{kg}$.$) , grams (\mathrm{g})$, centimeter $(\mathrm{cm})$, kilometers per hour $(\mathrm{km} / \mathrm{h})$ and seconds (sec).

The study involved 124 students, boys 50\% ( $\mathrm{n}=62)$ and girls $50 \%(\mathrm{n}=62)$, aged boys $11.94 \pm 0.39(10.91-12.91)$ and girls $11.85 \pm 0,45(11: 16-12.75)$. The average value of the tight mass of the observed population was $49.92 \mathrm{~kg}$. Girls (49.23 kg) were average lighter than boys $(50.51 \mathrm{~kg})$, but their average $\mathrm{BH}$ values were the same, $1.57 \mathrm{~cm}$.

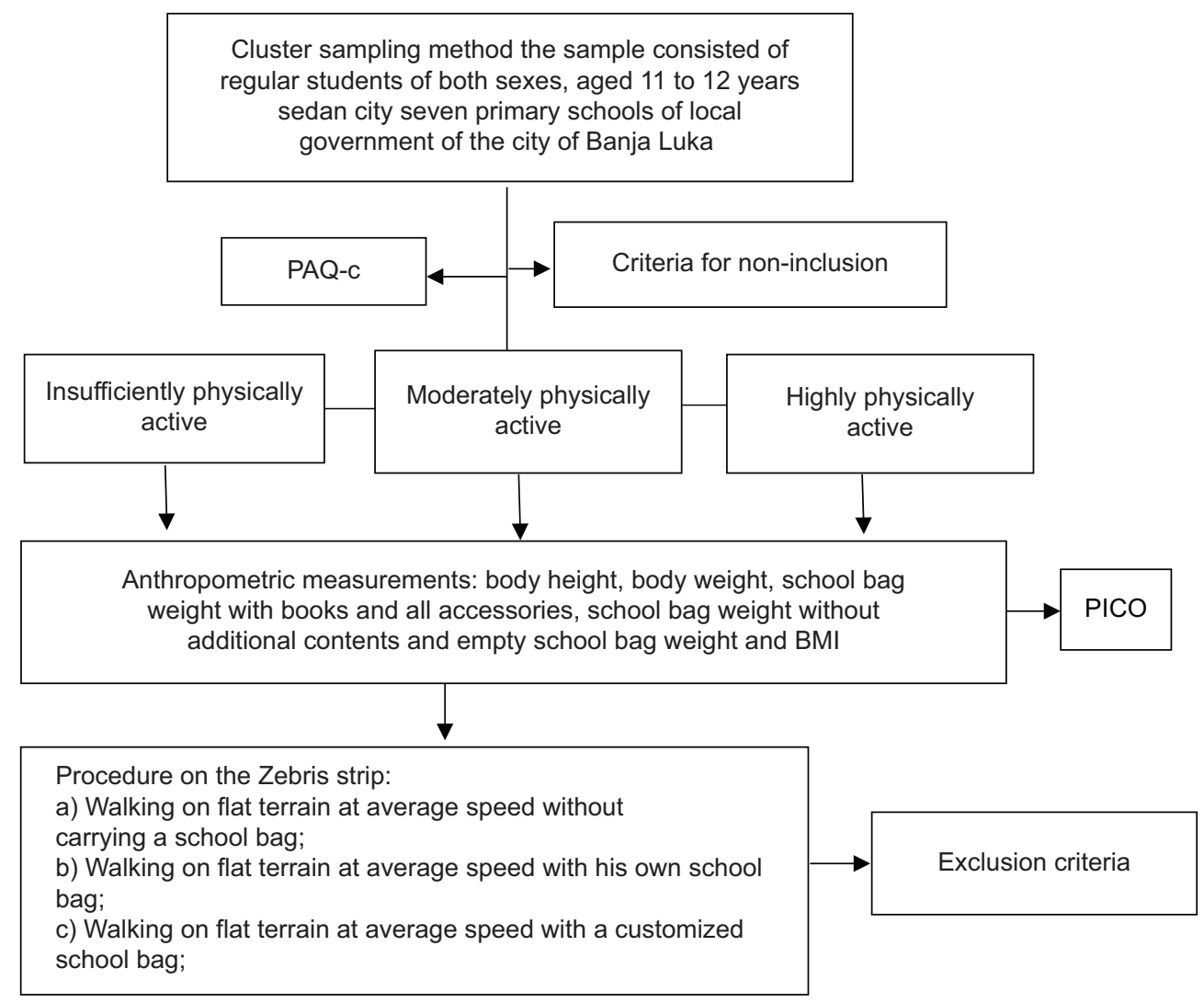

FIGURE 1. Population, sampling, and study protocol. 
TABLE 1. Descriptive analysis of anthropometric parameters of the sample for the total population and by sex. Values are expressed as MIN, $M A X$, and $A S \pm S . D$

\begin{tabular}{|c|c|c|c|c|c|c|c|c|c|c|c|c|c|c|c|}
\hline \multirow{3}{*}{$\begin{array}{l}\text { Anthropometric } \\
\text { characteristics }\end{array}$} & \multicolumn{15}{|c|}{ Gender } \\
\hline & \multicolumn{5}{|c|}{ Boys } & \multicolumn{5}{|c|}{ Girls } & \multicolumn{5}{|c|}{ Total } \\
\hline & $n$ & Mean & SD & Min & $\operatorname{Max}$ & $\mathrm{n}$ & Mean & SD & Min & $\operatorname{Max}$ & $\mathrm{n}$ & Mean & SD & Min & Max \\
\hline Body weight (BM) in $\mathrm{kg}$ & 62 & 50,61 & 12.16 & 30,10 & 89,10 & 62 & 49,23 & 12,89 & 27,50 & 83,80 & 124 & 49,92 & 12,49 & 27,50 & 89,10 \\
\hline $\mathrm{BH}$ in $\mathrm{cm}$ & 62 & 157,00 & 6,54 & 140 & 170 & 62 & 157,50 & 7,76 & 140 & 174 & 124 & 157,250 & 7,15 & 140 & 174 \\
\hline Age & 62 & 11,9394 & 0.38992 & 10,91 & 12,91 & 62 & 11,8505 & 0.45131 & 11,16 & 12,75 & 124 & 11,8950 & 0.42238 & 10,91 & 12,91 \\
\hline
\end{tabular}

BH: Body height, SD: Standard deviation

TABLE 2. Descriptive analysis of the school bag weight of the sample for the total population and by sex. Values are expressed as MIN, MAX, and $A S \pm S . D$

\begin{tabular}{|c|c|c|c|c|c|c|c|c|c|c|c|c|c|c|c|}
\hline \multirow[t]{3}{*}{ School bag features } & \multicolumn{15}{|c|}{ Gender } \\
\hline & \multicolumn{5}{|c|}{ Boys } & \multicolumn{5}{|c|}{ Girls } & \multicolumn{5}{|c|}{ Total } \\
\hline & $n$ & Mean & SD & Min & Max & $n$ & Mean & SD & Min & Max & $n$ & Mean & SD & Min & Max \\
\hline $\begin{array}{l}\text { The weight of an } \\
\text { empty bag, without } \\
\text { books in gr }\end{array}$ & 62 & 686,72 & 282,91 & 100 & 1500 & 62 & 563,71 & 289,03 & 100 & 1400 & 124 & 624,72 & 291,46 & 100 & 1500 \\
\hline $\begin{array}{l}\text { The weight of your } \\
\text { own bag with the } \\
\text { contents in gr }\end{array}$ & 62 & 5307,40 & 1191,77 & 3400 & 8300 & 62 & 5188,87 & 978,56 & 2900 & 7600 & 124 & 5248,14 & 1087,58 & 2900 & 8300 \\
\hline $\begin{array}{l}\text { Weight of own bag\% } \\
\text { of BM of child }\end{array}$ & 62 & 11,10 & 3,65 & 5,16 & 23,14 & 62 & 11,11 & 3,20 & 4,53 & 20,11 & 124 & 11,10 & 3,42 & 4,53 & 23,14 \\
\hline $\begin{array}{l}\text { Body weight + weight } \\
\text { of own bag } \mathrm{kg}\end{array}$ & 62 & 55,92 & 12,25 & 34,60 & 93,70 & 62 & 54,42 & 13,03 & 31,50 & 89,10 & 124 & 55,16 & 12,62 & 31,50 & 93,70 \\
\hline $\begin{array}{l}\text { Body weight + bag } \\
\text { weight of } 10 \% \text { BM kg }\end{array}$ & 62 & 55,13 & 12,76 & 33,11 & 93,70 & 62 & 53,68 & 13,55 & 30,25 & 89,10 & 124 & 54,41 & 13,03 & 30,25 & 93,70 \\
\hline
\end{tabular}

SD: Standard deviation

TABLE 3. Distribution of respondents in relation to BMl, school bag weight (by gender, and total)

\begin{tabular}{|c|c|c|c|c|c|c|c|}
\hline \multirow[t]{3}{*}{ Category } & \multirow[t]{3}{*}{ Parameters } & \multicolumn{4}{|c|}{ Gender } & \multicolumn{2}{|c|}{ Total } \\
\hline & & \multicolumn{2}{|c|}{ Boys } & \multicolumn{2}{|c|}{ Girls } & \multirow[b]{2}{*}{$\mathrm{n}$} & \multirow[b]{2}{*}{$\%$} \\
\hline & & $n$ & $\%$ & $n$ & $\%$ & & \\
\hline \multirow{6}{*}{$\begin{array}{l}\text { Body index } \\
\text { mass (BMI) }\end{array}$} & 1. & 21 & 33.9 & 12 & 19.4 & 33 & 26.6 \\
\hline & 2. & 7 & 11.3 & 9 & 14.5 & 16 & 12.9 \\
\hline & 3. & 27 & 43.5 & 28 & 45.2 & 55 & 44.4 \\
\hline & 4. & 7 & 11.3 & 9 & 14.5 & 16 & 12.9 \\
\hline & 5. & 0 & 0.0 & 4 & 6.5 & 4 & 3.2 \\
\hline & Total & 62 & 100.0 & 62 & 100.0 & 124 & 100.0 \\
\hline \multirow{6}{*}{$\begin{array}{l}\text { The weight } \\
\text { of your bag } \\
\text { (\% of BM) }\end{array}$} & 1. & 27 & 43.5 & 26 & 41.9 & 53 & 42.7 \\
\hline & 2. & 28 & 45.2 & 30 & 48.4 & 58 & 46.8 \\
\hline & 3. & 5 & 8.1 & 5 & 8.1 & 10 & 8.1 \\
\hline & 4. & 2 & 3.2 & 1 & 1.6 & 3 & 2.4 \\
\hline & 5. & 0 & 0,0 & 0 & 0,0 & 0 & 0,0 \\
\hline & Total & 62 & 100.0 & 62 & 100.0 & 124 & 100.0 \\
\hline
\end{tabular}

Body mass index: category 1-Obese> 97 percentile,
category 2- Increased body weight> 85 percentile, category 3- Normal body weight 15-85 percentile, category 4- Malnourished $<15$ percentile, category 5- Undernourished $<3$ percentile : Child's own weight $\%$ of TM: category 1. $<10 \% \mathrm{TM}$, category 2.>10\% TM, category 3.> 15\% TM, category 4.> $20 \%$ TM, category 5.> 25\% TM. BMI: Body mass index, BM: Body mass

The average weight of an empty school bag without books for the whole sample $(\mathrm{n}=124)$ was $624.72 \mathrm{~g}$. For girls, the empty bag averaged $563.71 \mathrm{~g}$, and for boys, $686.72 \mathrm{~g}$. The weight of their bag with teaching content averaged 5,248.14 g, for girls 5,188.87 g, and for boys $5307.40 \mathrm{~g}$. Regardless of gender, the $\%$ of school bag load concerning BM was approximately the same (11.06 \pm 3.65 ; 5.1623.14 in boys $),(11.11 \pm 3.20 ; 4.53-20.11$ in girls $)$. When

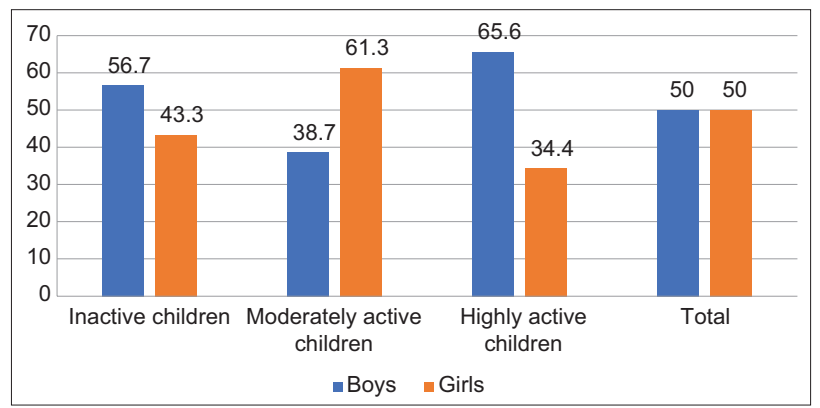

GRAPH 1. Level of physical activity with respect to gender and total sample. Physical activity test 1 - insufficiently physically active below the $25^{\text {th }}$ percentile, 2 - moderately physically active children from the $25^{\text {th }}$ to the $75^{\text {th }}$ percentile, and 3 - highly active children above the $75^{\text {th }}$ percentile.

carrying one's own bag for the observed population, the average body weight values were $55.16 \mathrm{~kg}$, and with an adapted school bag, $54.41 \mathrm{~kg}$.

Looking at Table 3, we notice that the average BMI in $26.6 \%$ of our sample was obese (boys $33.9 \%$ and girls $19.4 \%), 12.9 \%$ of overweight children, malnourished $12.9 \%$, and undernourished $3.2 \%$ of our sample. In our sample $(\mathrm{n}=124)$, no participants owned a school bag that was $>25 \%$ BM. The largest number of girls, $48.6 \%$ of our sample, had a school bag weight $>10 \%$ BM, and only $2.4 \%$ of the sample had a school bag weight $>20 \%$ BM. In $42.7 \%$ of the sample, the school bag was $<10 \% \mathrm{BM}$.

Looking at Graph 1, we notice that the largest percentage of respondents (38.7\% boys and $61.3 \%$ girls) is on average physically active, inactive children $(56.7 \%$ boys and $43.3 \%$ girls) and active children (65.6\% boys and $34.4 \%$ girls).

Looking at Table 4, during normal walking without a school bag, a statistically significant difference was found 
TABLE 4. Significant gait parameters of groups of inactive, averagely active, and active children registered during gait without a school bag, gait with their school bag, and gait with a custom school bag

\begin{tabular}{|c|c|c|c|c|c|c|}
\hline \multirow[t]{2}{*}{ Test } & \multirow[t]{2}{*}{$\begin{array}{l}\text { Stroke } \\
\text { parameter }\end{array}$} & \multicolumn{2}{|c|}{ Significance $^{1}$} & \multicolumn{3}{|c|}{$\begin{array}{l}\text { Groups of respondents, } \\
\text { mean, (pairwise } \\
\text { comparisons) }\end{array}$} \\
\hline & & $\mathrm{F}$ & Sig. & $\begin{array}{l}\text { Inactive } \\
\text { (1) }\end{array}$ & $\begin{array}{l}\text { Average } \\
\text { active (2) }\end{array}$ & $\begin{array}{c}\text { Active } \\
(3)\end{array}$ \\
\hline $\begin{array}{l}\text { Gait (without } \\
\text { school bag) }\end{array}$ & $\begin{array}{l}\text { Velocity, } \mathrm{km} / \\
\text { hour }\end{array}$ & 5.46 & 0.005 & 1.53 & $\begin{array}{c}1.71 \\
(1-2)^{*} ;(1-3)^{*}\end{array}$ & 1.73 \\
\hline \multirow[t]{4}{*}{$\begin{array}{l}\text { Gait (school } \\
\text { bag) }\end{array}$} & $\begin{array}{l}\text { Velocity, km/ } \\
\text { hour }\end{array}$ & 8.64 & 0.000 & 1.45 & $\begin{array}{c}1,69 \\
(1-2)^{*} ;(1-3)^{*}\end{array}$ & 1.71 \\
\hline & $\begin{array}{l}\text { Max force } \\
\text { heel left }\end{array}$ & 5.24 & 0.007 & 334.85 & $\begin{array}{l}245.37 \\
(1-2)^{*}\end{array}$ & 271.37 \\
\hline & $\begin{array}{l}\text { Max } \\
\text { pressure } \\
\text { heel left }\end{array}$ & 5.42 & 0.006 & 27.8 & $\begin{array}{l}20.23 \\
(1-2)^{*}\end{array}$ & 23.08 \\
\hline & $\begin{array}{l}\text { Max force } \\
\text { time } \% \text { of } \\
\text { stance time: } \\
\text { midfoot left }\end{array}$ & 3.498 & 0.033 & 48.83 & $\begin{array}{l}44.59 \\
(1-3)^{*}\end{array}$ & 40.31 \\
\hline \multirow{6}{*}{$\begin{array}{l}\text { Gait } \\
\text { (customized } \\
\text { school bag) }\end{array}$} & $\begin{array}{l}\text { Velocity, } \mathrm{km} / \\
\text { hour }\end{array}$ & 10.27 & 0.000 & \multicolumn{3}{|c|}{$(1-2)^{*} ;(1-3)^{*}$} \\
\hline & $\begin{array}{l}\text { Max force } \\
\text { heel left }\end{array}$ & 3.68 & 0.028 & 330.72 & $\begin{array}{c}265.93 \\
(1-2)^{*}\end{array}$ & 280.20 \\
\hline & $\begin{array}{l}\text { Max } \\
\text { pressure } \\
\text { heel left }\end{array}$ & 4.38 & 0.015 & 27.60 & $\begin{array}{l}21.85 \\
(1-2)^{*}\end{array}$ & 23.66 \\
\hline & $\begin{array}{l}\text { Time } \\
\text { change heel } \\
\text { to forefoot } \\
\text { sec left }\end{array}$ & 5.46 & 0.005 & 0.65 & $\begin{array}{c}0.47 \\
(1-2)^{*}\end{array}$ & 0.51 \\
\hline & $\begin{array}{l}\text { Max force } \\
\text { time } \% \text { of } \\
\text { stance time: } \\
\text { midfoot left }\end{array}$ & 3.087 & .049 & 47.69 & $\begin{array}{l}44.55 \\
(1-3)^{*}\end{array}$ & 39.76 \\
\hline & $\begin{array}{l}\text { Contact time } \\
\% \text { of stance } \\
\text { time:heel } \\
\text { left }\end{array}$ & 3.30 & 0.040 & 74.16 & 63.77 & 66.89 \\
\hline
\end{tabular}

$(1-2)^{*}$

${ }^{*} p<0.05 .{ }^{1} \mathrm{ANOVA}$, pairwise comparisons performed by Takey test

only at walking speed. Active children walked the fastest at $1.73 \mathrm{~km} / \mathrm{h}$, and inactive children walked the slowest at $1.53 \mathrm{~km} / \mathrm{h}$. Differences in walking speed were significant between all three groups, namely, inactive and moderately active children and between inactive and active children.

During normal walking with their own school bag, active children walked the fastest, at $1.71 \mathrm{~km} / \mathrm{h}$, and inactive children walked the slowest at $1.45 \mathrm{~km} / \mathrm{h}$. Differences in walking speed were significant between all three groups, namely, passive and moderately active children and between inactive and active children. The highest maximum force on the left heel is projected in inactive children, $334.85 \mathrm{~N}$, and the lowest $265.93 \mathrm{~N}$ in average active children. Differences in maximum force on the left heel were significant between inactive and moderately active children. The highest pressure on the left heel was found in inactive children, $27.8 \mathrm{~N} / \mathrm{cm}^{2}$, and the lowest average active children, $20.23 \mathrm{~N} / \mathrm{cm}^{2}$. Differences in maximal heel pressures were significant between inactive and moderately active children. The maximum force time of $\%$ of the standing time on the left foot in the middle part lasted $48.83 \%$ in inactive children compared to active children $40.31 \%$. During the walk with an adapted school bag, active children walked the fastest, $1.84 \mathrm{~km} / \mathrm{h}$, and the slowest inactive children, $1.49 \mathrm{~km} / \mathrm{h}$. Differences in walking speed were significant between all three groups, namely, inactive and moderately active children and between inactive and active children. The highest maximum force was registered on the left heel, $330.72 \mathrm{~N}$ in inactive children, and the lowest $265.93 \mathrm{~N}$ in average active children. The highest maximum pressure on the left heel was registered in inactive children, $27.60 \mathrm{~N} / \mathrm{cm}^{2}$, and the lowest $21.85 \mathrm{~N} / \mathrm{cm}^{2}$ in average active children. The change in time on the left foot from the heel to the front of the foot lasted the longest in inactive children, $0.65 \mathrm{~s}$, and the shortest $0.47 \mathrm{~s}$, as well as the contact time of \% standing on the left foot lasting $74.16 \%$ compared to the average active children $63.77 \%$. The maximum force time of $\%$ of the standing time on the left foot in the middle part lasted $47.69 \%$ in inactive children compared to active children $39.76 \%$.

\section{DISCUSSION}

To explain the results of our research, we should remind that a large number of the previous studies on posture, physical activity, and carrying a school bag in school-age children are aimed at identifying risk factors associated with back curvature, pain, and pain exhaustion. Moreover, the occurrence of fatigue using statistical indicators $(25,26)$. However, a number of authors in their research also focus on the analysis of the interaction between the legs and the ground $(9,27,28)$, pressures continue to cause some concern about the potential long-term negative effects on the foot structure and overall functionality of children.

The study involved 124 students, boys $50 \%(\mathrm{n}=62)$ and girls 50\% $(n=62)$, aged boys $11.94 \pm 0.39(10.91-12.91)$ and girls $11.85 \pm 0,45$ (11.16-12.75). The average value of $\mathrm{BM}$ of the observed population was $49.92 \mathrm{~kg}$ and $\mathrm{BH}$ $1.57 \mathrm{~cm}$. Girls are, on average, slightly lighter than boys. Compared to their peers from Serbia, they had a higher average $\mathrm{BM}$ but the same $\mathrm{BH}$ values. Still, compared to their peers from Montenegro, they had approximately the same average $\mathrm{BM}$ values and lower $\mathrm{BH}$ average values $(29,30)$. The smallest number of children in our study had a normal BMI. In $26.6 \%$ of the sample, BMI was in obese children, $12.9 \%$ were overweight, malnourished $12.9 \%$, and undernourished $3.2 \%$ of our sample indicating a significantly higher trend compared to previous studies that prevalence and the incidence of overweight and obesity in children in 2020 will amount to $14.1 \%$, compared to that of $7.9 \%$ in $1999(31,32)$.

The average weight of their bag with teaching content was $5248 \mathrm{~g}$. On average, the bag was $118 \mathrm{~g}$ lighter for girls than for boys. The results of our study were consistent with a literature review by Ellapen et al. (2021) that included 14 studies and 1061 participants, mean age $11.5 \pm 1.3$ years, body weight $37.8 \pm 6.6 \mathrm{~kg}$, height $1.41 \pm 0.05$ meters $(\mathrm{m})$, and backpack weight $5.2 \pm 0.9 \mathrm{~kg}$. The percentage of backpack weight in relation to the body weight of the respondents in our study was lower in relation to the authors' statement of $13.75 \%$. The study concludes that there is no consensus on the precise weight of backpacks that triggers postural 
changes (33). The average weight of an empty school bag without books for the whole sample $(\mathrm{n}=124)$ was $624.72 \mathrm{~g}$, for girls, the empty bag was on average lighter by $123.41 \mathrm{~g}$ than for the boys. The average value of BM when carrying your school bag was $750 \mathrm{~g}$ higher than when they carried a custom school bag. The obtained results confirm the original assumption that school bags are $10 \%$ heavier than the prescribed norms in the world, and according to the guidelines of the International Association of Pediatricians for Chiropractic, the American Academy of Orthopedic Surgeons the American Association of Occupational Therapists (12). The weight range of the school bag was minimal in boys $(3400 \mathrm{~g})$ and girls $(2900 \mathrm{~g})$, and maximum in girls (7600 g) and boys (8300 g), which is really alarming and speak of the excessive workload of the respondents. The maximum measured weight of an empty school bag for boys is $1500 \mathrm{~g}$ and a girl $1400 \mathrm{~g}$. The minimum weight of an empty school bag was $100 \mathrm{~g}$ both in boys and girls. If we look from the aspect of individual adjustment with regard to the recommendations of $10 \%$ of body weight, then it can be stated that the average minimum weight of a school bag has decreased by $290 \mathrm{~g}$ smaller, and the maximum weight of the school bag increased by $590 \mathrm{~g}$. We can explain this statement that in children whose BMI values are classified as obese, there was no adjustment of the weight of the school bag. For these reasons, it is not appropriate for all schoolchildren to have the same weight of a school bag. Obese schoolchildren should carry a lower weight ratio of backpacks to body weight, as both authors Adeyemi et al. (2015) noted (34). The conclusion of a study by Adeyemi et al. (2017) is that obese children are recommended to carry a third lighter burden than other children (35). Minimum measured BM values while carrying a boy's school bag $(34.60 \mathrm{~kg})$ and a girl $(31.50 \mathrm{~kg})$, and maximum BM values while carrying a boy's school bag $(93.7 \mathrm{~kg})$ and a girl $(89.10 \mathrm{~kg})$ which for the age population represents one range whose values in terms of showing the optimal weight and comparison with the optimal reference frames cannot be taken into account as given in the guidelines (12). The most significant number of children, $48.6 \%$ of our sample, had a school bag weight $>10 \%$ BM, and only $2.4 \%$ of the sample had a school bag weight greater than $20 \% \mathrm{BM}$ In $42.7 \%$ of the sample, the school bag was $<10 \%$ BM.

During the normal walk, the fastest active children walked $1.73 \mathrm{~km} / \mathrm{h}$, and the slowest inactive children $1.53 \mathrm{~km} / \mathrm{h}$. Differences in walking speed were significant between all three groups, namely inactive and moderately active children and between inactive and active children. The results of our study were in contrast to other studies that looked at detailed information on significant differences in the dynamic characteristics of the feet in subjects with normal weight, overweight, and obese children. The speed was $0.95 \pm 0.25 \mathrm{~m} / \mathrm{s}$, with no differences between normal weight, overweight, and obese children (36). In one study that aimed to examine the impact of physical activity on legs and plantar pressure in overweight and obese children. Included 73 overweight subjects and obese children (age 8.3 \pm 1.1 years; 47 girls and 26 boys; $\mathrm{z}$-score $\mathrm{BMI}=2.7 \pm 0.7$. Peak pressures were generated below the front of the foot during walking, and vice versa were correlated with time spent performing activities of different intensity levels. The conclusions of the study were consistent with the results of our study that children with higher pressure below the front and middle of the foot during normal walking had a lower level of physical activity (37). Structural changes associated with foot discomfort and increased plantar pressure may limit obese children to engage in physical activity (38). Author Paul et al. (2016), in their study, found that the distribution of pressure increased significantly in children with normal weight, but not in the overweight/obese group (15).

When the heel comes into contact with the ground, the muscles are in a negative phase, they lengthen because their force is less than the force of the load. With each contact, the feet with the ground form a greater reaction force than body weight. A statistically significant difference was observed in the force projected in the phase of contact of the heel with the ground on the left foot when carrying one's own and customized bag. The highest maximum force on the left heel was projected in inactive children, $334.85 \mathrm{~N}$, and the lowest $265.93 \mathrm{~N}$ in average active children when carrying their own but not an adapted school bag. The difference was also observed in the maximum pressure on the left heel when carrying their customized school bag. The highest pressure on the left heel was observed in inactive children, $27.8 \mathrm{~N} / \mathrm{cm}^{2}$, and on average active children $20.23 \mathrm{~N} / \mathrm{cm}^{2}$. Although the authors Paul et al. (2016) found that pressure values continue to raise some concerns regarding potential long-term negative effects on foot structure, particularly the functionality of overweight/obese children (15). Differences are also visible in the change of time from the heel to the front of the foot and the contact time of $\%$ standing on the left foot during the full support phase and which lasted the longest in inactive children and the shortest in average active children while carrying an adapted school bag. A statistically significant difference was observed in the maximum force time of $\%$ of standing time on the left foot in the middle, which lasted the longest in inactive children and the shortest active children when they carried their own $40.31 \%$ and a custom school bag $39.76 \%$. The results of our study were consistent with a study that reported that ergonomic intervention was effective in improving muscle strength and reducing pain intensity (39), but in contrast to other studies that reported that the gait of young adults could not be affected regardless of wearing a backpack or not, especially when walking short distances. The authors also concluded that no significant differences in gait parameters were observed between a regular backpack and a backpack with elastic straps. A backpack made of elastic straps cannot affect the gait, and that the design of the backpack must be more rigorous (40).

Based on the synthesis of the presented results, it is possible to conclude that the hypothesis was confirmed. The key findings are that active children during carrying an adapted school bag significantly reduced the time of force projected from the substrate, but not the generalization of the peak pressures.

No studies have been published in the Republika Srpska and the Federation of Bosnia and Herzegovina on the impact of carrying a school bag on the distribution of force and plantar pressure during normal walking of children of different levels of physical activity. Although it is a pilot study, the sample included a small number of children with a high level of physical activity. Therefore, initial research 
continues to better generalize the observed problems in the population under study.

\section{CONCLUSION}

The walking activity itself is performed in the aerobic range, but this activity must be viewed differently when the child performs it with loads such as carrying a school bag. Physical inactivity and unpreparedness of the organism to adequately respond to efforts affect all human organism systems, especially the locomotor system and the functionality of the feet. In moderately active children, the least pressure and force on the feet were projected because muscle contractions adequately responded to body weight. Active children walked the fastest while walking without a bag, with their own and customized school bag. The projection of force on the front of the foot of the left and right foot in active children was corrected when they carried an adapted bag in relation to their school bag. Moderate physical activity is crucial to respond to loads adequately and thus reduce the pressure and force exerted by the foot during walking activity. Still, a high level of physical activity while carrying an ergonomically adjusted school bag has significantly reduced the time of force projected from the ground.

\section{RECOGNITION}

The authors would like to express their gratitude to Professor Dubravko Bokonjić for his contribution to this work, which consisted of assistance for design and statistical analysis.

\section{CONFLICT OF INTERESTS}

Authors declare no conflict of interest.

\section{REFERENCES}

1. Grimmer $K A$, Jones $D$, Williams J. Prevalence of adolescent injury from recreational exercise: An Australian perspective. J Adolesc Health 2000;27(4):266-72. https://doi.org/10.1016/s1054-139x(00)00120-8.

2. Negrini S, Carabalona R. Backpacks on! Schoolchildren's perceptions of load associations with back pain and factors determining the load. Spine (Phila Pa 1976) 2002;27(2):187-95.

https://doi.org/10.1097/00007632-200201150-00014.

3. Trevelyan FC, Legg SJ. Back pain in school children-where to from here? Appl Ergon 2006;37(1):45-54

4. Kosinac Z. Hodanje i trčanje kao terapija i pozitivni atribut zdravlja. Život Škola 2012;27:153-66.

https://doi.org/10.1016/j.apergo.2004.02.008.

5. Piercy KL, Troiano RP, Ballard RM, Carlson SA, Fulton JE, Galuska DA, et al. The Physical Activity Guidelines for Americans. JAMA 2018;320(19):2020-8. https://doi.org/10.1001/jama.2018.14854.

6. Dianat I, Javadivala Z, Allahverdipour H. School bag weight and the occurrence of shoulder, hand/wrist and low back symptoms among Iranian elementary schoolchildren. Health Promot Perspect 2011;1(1):76-85

7. Ramadan MZ, Al-Shayea MA. A modifed backpack design for male school children. Int $J$ Ind Ergon 2013;43:462-71.

8. Mackie HW, Legg SJ. Postural and subjective responses to realistic schoolbag carriage. Ergonomics 2008;51(2):217-31. https://doi.org/10.1080/00140130701565588.

9. Singh $\mathrm{T}$, Koh M. Effects of backpack load position on spatiotemporal parameters and trunk forward lean. Gait Posture 2009;29(1):49-53. https://doi.org/10.1016/j.gaitpost.2008.06.006.

10. Pau M, Pau M. Postural sway modifications induced by backpack carriage in primary school children: A case study in Italy. Ergonomics 2010;53(7):872-81. https://doi.org/10.1080/00140139.2010.489965.

11. Chow DH, Leung KT, Holmes AD. Changes in spinal curvature and proprioception of schoolboys carrying different weights of backpack. Ergonomics 2007;50(12):2148-56. https://doi.org/10.1080/00140130701459832.

12. Cavallo CM, Hlavaty TM, Tamase MG. A pilot study for the development of a primary prevention program: What is the average weight of a fourth Grader's backpack? Work 2002;20(2):137-58.

13. Hong $Y$, Brueggemann GP. Changes in gait patterns in 10-year-old boys with increasing loads when walking on a treadmill. Gait Posture 2000;11(3):254-9. https://doi.org/10.1016/s0966-6362(00)00055-2.

14. Štefan L, Kasovi'c, M, Zvonar M. Association between the levels of physical activity and plantar pressure in 6-14-year-old children. PeerJ 2020;8:e8551. https://doi.org/10.7717/peerj.8551.

15. Pau M, Leban B, Corona F, Gioi S, Nussbaum MA. School-based screening of plantar pressures during level walking with a backpack among overweight and obese schoolchildren. Ergonomics 2016;59(5):697-703. https://doi.org/10.1080/00140139.2015.1077275.

16. Walsh TP, Butterworth PA, Urquhart DM, Cicuttini FM, Landorf KB, Wluka AE, et al. Increase in body weight over a two-year period is associated with an increase in midfoot pressure and foot pain. J Foot Ankle Res 2017;10:31. https://doi.org/10.1186/s13047-017-0214-5.

17. Association AOT. Backpack-Related; 2014. Available from: Available from: https:// www.aota. org/ConferenceEvents/Backpack-Safety-AwarenessDay/Handouts.aspx Last access: 02. Jun. 2021.

18. Samaržija DV, Mišigoj-Duraković M. Pouzdanost hrvatske verzije upitnika za procjenu ukupne razine tjelesne aktivnosti djece mlaðe školske dobi. Hrvatski Športskomedicinski Vjesnik 2013;28(1):24-32.

https://doi.org/10.15291/magistra.1326.

19. Kowalski KC, Crocker PR, Donen RM. The physical activity questionnaire for older children (PAQ-C) and adolescents (PAQ-A) manual. Coll Kinesiol Univ Saskatchewan 2004;87(1):1-38.

20. World Health Organization. Recommended Levels of Physical Activity for Children Aged 5-17 Godina. Global Strategy on Diet, Physical Activity and Health. Geneva: World Health Organization; 2010-2011.

21. Balamurugan J. School bags and musculoskeletal pain among elementary school children in Chennai city. Int J Med Sci Clin Invent 2014;1:302-9.

22. Džibrić D, Pejić J, Huremović T, Bukvić A, Nišić E. Razlike odnosa mase tijela mase školske torbe između učenika različith razreda Difference between body masses and school chassis mases between different distinctive teachers. 10. Međunarodni Sinpozijum Sport i Zdravlje.,Tuzla 2017; 60-65. [Internet]. [Cited Available from: https://www.researchgate.net/profile/Edin_Mujanovic/publication/324007189_Povezanost_sastava_tijela_sa_uspjehom_u_izvodenju_nekih elemenatatehnike_skijanja_Corelation_of_body_composition_with_success_ in_some_elements_of_skiing_techniques/links/5ab8bcada6fdcc46d3b89b72/ Povezanost-sastava-tijela-sa-uspjehom-u-izvodenju-nekih-elemenatatehnikeskijanja-Corelation-of-body-composition-with-success-in-some-elements-of-skiing-techniques.pdf Last access: 14. Jul.2021

23. McSweeney SC, Reed LF, Wearing SC. Reliability and minimum detectable change of measures of gait in children during walking and running on an instrumented treadmill. Gait Posture 2020;75:105-8.

https://doi.org/10.1016/j.gaitpost.2019.10.004.

24. Zebris FDM 1.12. Software User Manual, 2015. [Internet] Available from: https://www. hpcosmos.com/sites/default/files/uploads/documents/20150709_cos102245man-en_ instruction_for_use_software_zebris_fdm_1.12_r2_en_0.pdf.

Last access: 14. Jul. 2021

25. Laštro D, Ivetić V, Pilipović Spasojević O, Jandrić S, Spasojević G. Uticaj fizičke aktivnosti na držanje tijela djece školskog uzrasta. Glasnik Antropološkog Društva Srbije Niš 2015;50:79-87.

https://doi.org/10.5937/gads1550079|

26. Laštro D, Pilipović-Spasojević 0 . Sedentary and dynamic activities of adolescents as predictions of postural status. Med Časopis 2017;51(4):118-25. https://doi.org/10.5937/mckg51-16251.

27. Pau M, Mandaresu S, Leban B, Nussbaum MA. Short-term effects of backpack carriage on plantar pressure and gait in schoolchildren. J Electromyogr Kinesiol 2015;25(2):406-12.

https://doi.org/10.1016/j.jelekin.2014.11.006

28. Kim K, Kim CJ, Oh DW. Effect of backpack position on foot weight distribution of school-aged children. J Phys Ther Sci 2015;27(3):747-9. https://doi.org/10.1589/jpts.27.747.

29. Vukićević V, Lukić N, Zečević S. Connection of Anthropometric Indicators and Motor Abilities of Primary School Students. SPORT - Science and Practice 2020;10:1: 5-176. [Internet]. Available from: CONNECTION OF ANTHROPOMETRIC INDICATORS AND.http://sportnaukaipraksa.vss.edu.rs > pdf , SNP-10-01_EN. Last access: 14. Jul. 2021.

30. Zovko IC, Mitrovic M, Corluka M. Comparative analysis of anthropometric parameters as obesity indicators for sixth grade boys from different regions in montenegro. J Anthropol Sport Phys Educ 2020;4(4):27-31.

31. de Onis M, Blössner M. Borghi E. Global prevalence and trends of overweight and obesity among preschool children. Am J Clin Nutr 2010;92(5):1257-64. 
https://doi.org/10.3945/ajcn.2010.29786.

32. Asadi-Melerdi S, Rajabi-Shamli E, Sheikhhoseini R, Piri H. Association of upper quarter posture with depression, anxiety, and level of physical activity in sixth grade elementary school students of Karaj city, Iran. Int J Sch Health 2020;7(1):48-55.

33. Ellapen TJ, Paul Y, Hammill H V, Swanepoel M. Altered cervical posture kinematics imposed by heavy school backpack loading: A literature synopsis (2009-2019). Afr J Disabil 2021;10:687. https://doi.org/10.4102/ajod.v10i0.687.

34. Adeyemi AJ, Rohani JM, Rani MR. Interaction of body mass index and age in muscular activities among backpack carrying male schoolchildren. Work 2015;52(3):677-86. https://doi.org/10.3233/wor-152102.

35. Adeyemi AJ, Rohani JM, Rani MR. Backpack-back pain complexity and the need for multifactorial safe weight recommendation. Appl Ergon 2017;58:573-82. https://doi.org/10.1016/j.apergo.2016.04.009.

36. Mueller S, Carlsohn A, Mueller J, Baur H, Mayer F. Influence of obesity on foot loading characteristics in gait for children aged 1 to 12 years. PLoS One 2016;11(2):e0149924. https://doi.org/10.1371/journal.pone.0149924.

37. Riddiford-Harland DL, Steele JR, Cliff DP, Okely AD, Morgan PJ, Jones RA, et al. Lower activity levels are related to higher plantar pressures in overweight children. Med Sci Sports Exerc 2015;47(2):357-62.

https://doi.org/10.1249/mss.0000000000000403.

38. Dowling AM, Steele JR, Baur LA. Does obesity influence foot structure and plantar pressure patterns in prepubescent children? Int J Obes Relat Metab Disord 2001;25:845-52.

https://doi.org/10.1038/sj.ijo.0801598.

39. Huang Z, Sui X, He X. Spatial-temporal and kinematic characteristics of gait carrying loaded backpack with elastic straps. Filomat 2020;34(15):5207-13.

https://doi.org/10.2298/fil2015207h.

40. Waradkar CP, Palsule SP. Effectiveness of an ergonomic intervention program in college students carrying backpack in a Metropolitan city. Int J Health Sci Res 2021;11(2):157-70.

\section{RELATED ARTICLES PUBLISHED IN JHSCI}

1. Halilbašić A, Kreso A, Klepić M, Jaganjac A, Avdic D. The Algorithm for overload syndrome prevention: OsgoodSchlatter's syndrome (OSD) as an overload syndrome caused by early inclusion of children in sports and excessive physical activity (sports and recreation). JHSCI;9(3):151-8.

2. Mačak Hadžiomerović A, Jaganjac A, Avdic D, Švraka E, Pašalić A, Kaljić E, Domljan D, Omerović E. School bags and associated back pain. JHSCI. 2018;8(1):10-9. 